чином виробничого навчання формуються творча активність, самостійність, чітка професійна позиція, компетентність та професійний універсалізм майбутнього спеціаліста. Найбільш важливими і досі проблемними лишаються такі задачі організації освітнього процесу нового типу: зміна ставлення до змісту освіти як до синтезу самоосвіти, самоорганізації та самовиховання; зміна мотивації суб'єктів освітнього процесу шляхом створення умов для їхньої самореалізації (що неможливо у закритому освітньому просторі без консолідації зусиль різних організацій, установ, підприємств); забезпечення інноваційної освітньої системи в фінансовому, матеріально-технічному, юридичному та психолого-педагогічному плані; підготовка і залучення педагогічних кадрів нового типу.

Ключові слова: система освіти, освітні технології, навчально-тренувальна фірма, імітаційна технологія навчання, реформування освіти.

Submitted on May, 22, 2017

UDC: $378.147: 004.4: 5$

DOI: https://doi.org/10.24195/2414-4665-2017-6-10

Ihor Puchkov,

ces), associate professor,

Vladyslav Sariienko,

PhD (Candidate of Pedagogical Sciences), associate professor,

Volodymyr Sariienko,

PhD (Candidate of Pedagogical Sciences), associate professor, Department of Science Disciplines and Mathematics, Donbas State Pedagogical University, 19, H. Batiuka, Sloviansk, Ukraine,

\title{
DIDACTIC FOUNDATIONS OF SOFTWARE STRUCTURING IN THE PROCESS OF TEACHING SCIENCE DISCIPLINES AND MATHEMATICS AT PEDAGOGICAL UNIVERSITIES
}

Science disciplines and Mathematics are considered to be a fundamental evidential and technical base of modern researches and production; they contribute to the formation of scientific worldview, intellectual development, provide acquisition of knowledge and skills necessary for working with a PC. When developing the technology of structuring software for teaching science disciplines and Mathematics at pedagogical universities one should regard that it must cover all structural components of the educational process (target, motivational, content, operative and regulative, as well as estimation and result). The relevance of the research is explained by the necessity of determining didactic foundations of software structuring in the process of teaching scientific disciplines and Mathematics, as it affects the level of future teachers' professional competence. The paper aims to prove the necessity of software structuring as a way of achieving the optimal combination of different program teaching methods which provides the development of students' self-study skills in the process of mastering scientific disciplines and Mathematics. The has been conducted the pedagogical experiment aimed at checking the efficiency of the developed technique of structuring the software for teaching science disciplines and Mathematics at the Department of Physics and Mathematics of Donbas State Pedagogical University involving $1202^{\text {nd }}-5^{\text {th }}$ year students divided into control and experimental groups. The checking was carried our according to the following criteria: motivational; cognitive; vocational. Pearson's chi-squared test $(\chi 2)$ was used for the research outcomes verification. The carried out pedagogical experiment has proved the expediency of the developed technology of software structuring in the process of teaching scientific disciplines and Mathematics, which provides the increase of the level of students' professional competence.

Keywords: pedagogical experiment, software, structuring, teaching, science disciplines, mathematics, professional competence.

\section{Introduction}

One of the priority areas of modern higher pedagogical education development is active implementation of various computer technologies into the educational process, which significantly improve the quality of training. Their application involves reinterpretation of the basic structural components of teaching and learning: goals, content, methods, organizational forms, evaluation crite- ria, and correction of the obtained results if necessary. In view of this, the need for the development of modern software for teaching students in general, and determination of didactic foundations of its structuring in particular, are of great importance [6], [7].

In the process of training future teachers special attention is paid to science disciplines and Mathematics because they are regarded as a fundamental evidential and 
technical base of modern researches and production, besides, they contribute to the formation of scientific worldview, intellectual development, provide the acquisition of knowledge and skills necessary for working with a PC. In view of this, the issue of the development of relevant software for teaching science disciplines and Mathematics at pedagogical universities as one of the factors of educational process improvement, is considered to be urgent today.

Scientists deal with this issue in various directions, for instance, in the field of development of scientific and methodical foundations of education computerization (the issue was studied by B. Hershunskyi, M. Zhaldak, V. Monakhov, N. Morze, Yu. Pervin, W. Halal, D. Langenberg), in the field of applying modern ICT in the educational process (V. Diakonov, S. Rakov, M. Holovan, T. Zaitseva and others), in the area of examining main requirements to the development of methodical software for teaching students (N. Holovchak, Yu. Trius, V. Sharavin, S. Yailakhanov and others), studying methodical systems of teaching science disciplines and Mathematics at general and higher educational institutions (T. Boronenko, O. Ionova, V. Klochko, N. Morze, Z. Sliepkan and others).

Taking into account the significant contribution of the carried our research studies it is worth noting that there are some challenges in the development of software for teaching science disciplines and Mathematics at pedagogical universities, particularly in the field of software structuring. The software structuring is determining it as a system object and dividing it into certain structural units. Didactic foundations of this process involve principles, aim, content, and the technology. In particular, the process of software structuring should comply with the following principles: unity of educational and upbringing functions of education, scientific character, consistency, active and independent character, demonstrativeness, connection of learning with practical work $[1 ; 5 ; 6 ; 7 ; 10]$.

Addressing this challenge helps to solve a number of urgent didactic tasks: for instance, educational process activation, development of cognitive independence, formation of creative cognitive skills in the process of studying science disciplines and Mathematics by students using computer technologies [8].

The issue of cognitive processes activation has been studied for many years and still remains relevant. However, the intense development of computer technologies has revealed new approaches to address this challenge, though new tasks have arisen as well. Thus, one of the tasks focused on the improvement of the efficiency of using computer technologies concerning this issue is the software structuring.

The paper aims to examine the need for software structuring for teaching science disciplines and Mathematics as a way of achieving optimal unity of program and other kinds of teaching which provides the development of students' self-study skills; to check the efficiency of the developed technique of software struc- turing.

The research hypothesis implies that the structuring of software for teaching science disciplines and Mathematics at pedagogical universities, which covers all the components of the educational process (target, motivation, content, regulative, as well as evaluation and result), will both contribute to the increase of future teachers' professional competence and create a structural basis for the development of students' self-study skills.

The intense development of computer techniques and ICT causes the necessity of their active implementation into the educational process of institutions of various types, including higher education [12]. The use of these technologies contributes to the increase of the quality of training, provides acquisition of knowledge and skills by students, which they need in their future work. In its turn, this requires the development of a relevant software support, which will help to apply various computer technologies in the educational process. It concerns first of all higher pedagogical institutions as they aim not only to provide students with knowledge and skills but also help them master methods of teaching computer disciplines and ICT for teaching other subjects.

It is obvious that software for teaching science disciplines and Mathematics significantly differs from that for teaching humanities. That is why it is worth paying special attention.

The software for teaching science disciplines and Mathematics includes the following tools: online courses, various educational websites, e-textbooks, e-laboratory facilities, university website, etc. [8].

In the process of developing the technology for science disciplines and Mathematics software structuring at pedagogical universities one should remember that it should cover all structural components of the educational process: target (which implies teacher's awareness and students' perception of the aim and tasks of studying a topic, unit or the whole course); motivational (which provides stimulating students' interest in the subject studied), content (determined by the curriculum, textbooks), regulative (which requires simultaneous assessment of the educational process and its results both by a teacher and students); evaluation and result (oriented at the assessment of students' academic performance by a teacher, making conclusions about the achievement (or failure) of education aims and tasks, etc.) [5]. This approach helps to find out what structural units of the software should be combined in order to provide the efficient functioning of each one.

Software, depending on the kind of the created environment, can be conditionally divided into the following three categories: system, instrumental and applied. The system software is a complex of common programs providing interaction between a person, devices and computer programs. The instrumental software helps to create new computer programs using software language, in other words it includes programming tools [2]. The applied one involves all computer programs providing users with an 
opportunity to give certain tasks to a computer.

When realizing the target component thorough attention should be paid to encouraging students to work with a university website. For example, when working on the portal of Donbas State Pedagogical University its developers took into account that it was designed to be a corporate system providing access to the educational process scheme, and also that it integrated into the common informational and educational environment of the national level giving access to outside users. Besides, the university also has inside computer networks uniting all faculty computers with information upgrading and having internet access.

The access to the university website as well as to the resources of its inside educational network gives students an opportunity to get timely information about the determined current goals of studying science disciplines and Mathematics, periods and ways of their achievement, master education goals when working with other computer tools, for example, e-textbooks. Besides, teachers explained the tasks which should be solved at each lesson, how the suggested kinds of work help to achieve the goals of studying every subject. Thus, future teachers get access to printed educational complexes, which help them to specify the aim and tasks for various disciplines.

At the stage of motivational component realization, thorough attention should be paid to the development of cognitive and social motives necessary for both: studying the scientific disciplines and Mathematics, and students' professional competence formation. In this regard, students are taught the history of the development of mathematics, physics, informatics, and the most prominent achievements in this field, provide their understanding of social mission of a teacher, which requires students to have pedagogical mastery skills.

Computer tools are of great importance at this stage of the educational process, as they combine different means of demonstrativeness, increase students' interest in the subject, etc.

We believe that students should be encouraged to prepare various kinds of e-portfolios, which will motivate them to self-development. For instance, during the experiment the students were suggested to create portfolioreports about studying the most difficult topics in scientific disciplines and Mathematics; portfolio-self-report about their preparation for colloquiums on various subjects; academic performance portfolio in which they presented their achievements in studying science disciplines and Mathematics by applying computer means; reflexive portfolio which would demonstrate the results of their reflexive activity in the process of studying science disciplines and Mathematics.

As it was mentioned before, studying science disciplines and Mathematics is a component of the general process of future teachers' (in the correspondent field) training, which involves the need for attracting their attention to self-development, determination of social motives. That is why future teachers should be encouraged to make career portfolios, which would demonstrate their professional development. It is worth mentioning that during the experiment many students uploaded their portfolios in the internet which helped to establish business contacts.

The third component - content - is considered to be of the key importance in the educational process. During the experiment the developed software allowed to computerize all the teaching forms: lectures, seminars, practical classes, laboratory practicals, etc. At this stage there were applied computer (electronic) textbooks, programs, automatized training systems, computer laboratory practicals, etc. When presenting new material at the lecture a teacher can use computer equipment for demonstrating relevant schemes, figures, photos, videos, etc.

We used automatized and expert teaching systems, etextbooks, automatized knowledge assessment systems, etc. in order to implement regulative and resultative educational process components.

\section{Research methods}

We conducted the pedagogical experiment aimed at checking the efficiency of the developed technique of structuring the software for teaching science disciplines and Mathematics at the Department of Physics and Mathematics of Donbas State Pedagogical University.

The checking was carried our according to the following criteria: 1) motivational: students' motives to study scientific disciplines and Mathematics (was conducted by means of questioning); 2) cognitive: the level of students' academic performance in scientific disciplines and Mathematics (knowledge evaluation analysis); 3) vocational: the quality of acquired knowledge and skills of using computer technologies for teaching scientific disciplines and Mathematics (analysis of addressing educational tasks during teaching practice/internship).

The experiment involved $1202^{\text {nd }}-5^{\text {th }}$ year students divided into control and experimental groups.

Pearson's chi-squared test $\left(\chi^{2}\right)$ was used for the research outcomes verification.

\section{Research results and their discussion}

Taking into account the determined criteria we have distinguished three levels of the students' professional competence maturity in the context of their mastering science disciplines and Mathematics: high, average, and low. Also we kept in mind that in scientific literature [4], [9], the term "level" is usually used to determine the degree of the development (of a quality, value).

The data obtained according to the motivation criterion demonstrate that the variability ratio of the high level of motives to studying science disciplines and Mathematics was 1.21 in the EG and 1.05 - in the CG. The variability ratio of the average level was 0.9 in the EG and $0.98-$ in the CG. The variability ratio of the low level was 0.86 in the EG and 0.96 - in the CG.

The results obtained according to the cognitive criterion show that the that the variability ratio of the high level of students' academic performance in science disciplines and Mathematics was 1.2 in the EG and 1.03 - in the $\mathrm{CG}$; the variability ratio of the average level of stu- 
dents' academic performance in science disciplines and Mathematics was 0.91 in the EG and 0.98 - in the CG; the variability ratio of the low level of students' academic performance in science disciplines and Mathematics was 0.88 in the EG and 0.98 - in the CG.

Concerning the third criterion (vocational) the variability ratio of the high level of students' knowledge and organizational skills of using CT in the process of teaching science disciplines and Mathematics was 1.18 in the EG and 1.01 - in the CG; the variability ratio of the average level of students' knowledge and organizational skills of using CT in the process of teaching science disciplines and Mathematics was 0.91 in the EG and 0.98 - in the CG; the variability ratio of the low level of students' knowledge and organizational skills of using CT in the process of teaching science disciplines and Mathematics was 0.9 in the EG and the results of the CG did not change.

After having generalized the data and calculating the results, we have determined the number of students of each group having certain level of professional competence before and after the experiment. The results are presented in Table 1.

Levels of the respondents' professional competence maturity (generalized data)

Table 1.

\begin{tabular}{|c|c|c|c|c|}
\hline \multirow{2}{*}{ levels } & \multicolumn{2}{|c|}{ EG $(\mathrm{n}=60)$} & \multicolumn{2}{c|}{ CG (n=60) } \\
\cline { 2 - 5 } & Summative assessment & $\begin{array}{c}\text { Formative assess- } \\
\text { ment }\end{array}$ & $\begin{array}{c}\text { Summative assessment } \\
\text { Formative assess- } \\
\text { ment }\end{array}$ \\
\hline High & 5 students & 17 students & 4 students & 6 students \\
\hline Average & 42 students & 37 students & 44 students & 43 students \\
\hline Low & 13 students & 6 students & 12 students & 11 students \\
\hline
\end{tabular}

Thus, we can conclude that according to all the determined criteria and indicators we can observe the most mature professional competence in the students of the experimental group. It allows to state that the developed technology of structuring the software for teaching science disciplines and Mathematics provides the increase of future teachers' level of professional competence.

$$
T \exp =\frac{1}{N_{1} N_{2}} \sum_{i=1}^{3} \frac{\left(N_{1} Q_{2 i}-N_{2} Q_{1 i}\right)^{2}}{Q_{1 i}+Q_{2 i}} \text { [3], }
$$

For the significance level $\alpha=0,05$ and the number of degrees of freedom $v=c-1=2 \mathrm{~T}_{\text {crit }}=6$. In our case $T_{\text {exp }} \approx 7,2$, which means $T_{\text {exp }}>\mathrm{T}_{\text {crit. }}$. As a result, we assume the alternative hypothesis: the differences between the distribution of the students of EG and CG according to the levels of professional competence are statistically significant with a probability of $95 \%$.

Thus, the data obtained prove the hypothesis which implies that the implementation of the developed technique of structuring the software for teaching science disciplines and Mathematics increases the level of student' professional competence both in the field of acquiring the disciplines' content and developing cognitive motivation.

\section{Conclusions}

\section{REFERENCES}

1. Burynska, N. M. (1999). Dydaktychni osnovy shkilnoho pidruchnyka z pryrodnychykh dystsyplin [Didactic fundamentals of school textbook of natural sciences]. Pedahohika i psykholohiya - Pedagogy and Psychology, 3, 23-28 [in Ukrainian].

2. Gagarina, L. G. (2008). Tekhnologiна razrabotki programmnogo obespecheniнa [Technology of software
In order to verify the results, we have used Pearson's chi-squared test $\left(\chi^{2}\right)$. At first there were formulated null and alternative hypotheses to check the revealed differences in the levels of students' professional competence.

$\mathrm{T}_{\exp }$ is calculated according to the following formula: 
4. Nemov, R. S. (1995). Psikhologiia: Eksperimentalnaia psikhologiia $i$ psikhodiagnostika [Psychology: Experimental psychology and psychodiagnostics]. Moscow: Prosveshchenie [in Russian].

5. Pedagogika [Pedagogy] (1983). Moscow: Prosveshchenie [Russian].

6. Puchkov, I. R. (2013). Dydaktychni zasady strukturuvannya prohramnoho zabezpechennya navchannya fizyko-matematychnykh dystsyplin u pedahohichnykh universytetakh [Didactic principles of structuring software for teaching physical and mathematical sciences at pedagogical universities]. Extended abstract of candidate's thesis. Kharkiv: Khark. nats. ped. un-t im. H. S. Skovorody [in Ukrainian].

7. Puchkov, I. R. (2012). Sut i dydaktychni pryntsypy strukturuvannya prohramnoho zabezpechennya navchannya fizyko-matematychnykh dystsyplin [Essence and didactic principles of structuring software for teaching physical and mathematical sciences]. Humanizatsiya navchalno-vykhovnoho protsesu - Humanization of the educational process, 59, 350 [in Ukrainian].

\section{ЛІТЕРАТУРА}

1. Буринська Н. М. Дидактичні основи шкільного підручника 3 природничих дисциплін / $\mathrm{H}$. М. Буринська // Педагогіка і психологія. - 1999. - № 3. - C. 23-28.

2. Гагарина Л. Г. Технология разработки программного обеспечения / Л. Г. Гагарина, Е. В. Кокорева, Б. Д. Виснадул. - М. : ИД «ФОРУМ»; ИНФРА-М, 2008.

3. Грабарь М. И. Применение математической статистики в педагогических исследованиях / М. И. Грабарь, К. А. Краснянская. - М. : Педагогика, 1977. - $136 \mathrm{c}$

4. Немов Р. С. Психология: учеб / Р. С. Немов // В 3 кн. - Кн. 3 : Экспериментальная психология и психодиагностика. - М. : Просвещение : ВЛАДОС, 1995. $-512 \mathrm{c}$.

5. Педагогика : учеб. пособ. / Под ред. Ю. К. Бабанского. - М. : Просвещение, 1983. - 608 с.

6. Пучков I. Р. Дидактичні засади структурування програмного забезпечення навчання фізикоматематичних дисциплін у педагогічних університетах : автореф. дис. ... канд. пед. наук : 13.00.09 / Ігор Русланович Пучков. - Харк. нац. пед. ун-т ім. Г. С. Сковороди. - Харків, 2013. - 20 с.
8. Sariyenko, V. V. (2015). Rozvytok tvorchoi piznavalnoi diialnosti starshoklasnykiv $\mathrm{u}$ protsesi navchannya predmetiv pryrodnycho-matematychnoho tsyklu [Development of creative cognitive activity of senior pupils in the process of learning scientific disciplines and Maths]. Extended abstract of candidate's thesis. Kharkiv: Khark. nats. ped. un-t im. H. S. Skovorody [in Ukrainian].

9. Stoliarov, V. I. (1996). Progress izmeneniia i ego poznanie. Logiko-metodologicheskie problemy [Progress of change and its cognition]. Moscow: Nauka [in Russian].

10. Chayka, V. (2002). Osnovy dydaktyky: Teksty lektsiy $i$ zavdannya dlya samokontrolyu [Bases of didactics: texts of lectures and tasks for self-assessment]. Ternopil: Aston [in Ukrainian].

11. Halal, W. E. (1992). The information technology revolution, 26, 10-14. Washington [in English].

12. Langenberg, D. N. (1994). Information technology and the university: Integration strategies for the 21st century, 45, 323-325. Washington: J. Amer. Soc. Inform. Science [in English].

7. Пучков I. Р. Суть і дидактичні принципи структурування програмного забезпечення навчання фізико-математичних дисциплін / I. Р. Пучков // Гуманізація навчально-виховного процесу: Зб.наук.праць. Вип. LIX. - Слов'янськ: СДПУ, 2012. - 350 с.

8. Сарієнко В. В. Розвиток творчої пізнавальної діяльності старшокласників у процесі навчання предметів природничо-математичного циклу : автореф. дис. ... канд. пед. наук : 13.00 .09 / Володимир

Владиславович Сарієнко. - Харків. нац. пед. ун-т імені Г. С. Сковороди. - Харків, 2015. - 20 с.

9. Столяров В. И. Прогресс изменения и его познание. Логико-методологические проблемы / В. И. Столяров. - М. : Наука, 1996. - 252 с.

10. Чайка В. Основи дидактики : Тексти лекцій i завдання для самоконтролю: навч. посіб. / В. Чайка. Тернопіль : Астон, 2002. - 244 с.

11. Halal W. E. The information technology revolution / W. E. Halal // Futurist. - Washington, 1992. - V.26, N 4. - P.10-15.

12. Langenberg D. N. Information technology and the university: Integration strategies for the 21 st century / D. N. Langenberg // J. Amer. Soc. Inform. Science. Washington, 1994. - V. 45. - №5. - P. 323-325. 
Ігор Русланович Пучков, кандидат педагогічних наук, дочент, Владислав Костянтинович Сарієнко, кандидат педагогічних наук, дочент, Володимир Владиславович Сарієнко, кандидат педагогічних наук, дочент, кафедра природничо-математичних дисциплін, Донбаський державний педагогічний університет,

вул. Г. Батюка, 19, м. Слов'янськ, Украӥна

\section{ДИДАКТИЧНІ ЗАСАДИ СТРУКТУРУВАННЯ \\ ПРОГРАМНОГО ЗАБЕЗПЕЧЕННЯ ПРИ НАВЧАННІ ПРЕДМЕТІВ ПРИРОДНИЧО-МАТЕМАТИЧНОГО ЦИКЛУ У ПЕДАГОГІЧНИХ УНІВЕРСИТЕТАХ}

Дисципліни природничо-математичного циклу становлять фундаментальну доказову i технікоконструктивну базу сучасних наукових досліджень і виробництва, сприяють формуванню наукового світогляду, інтелектуальному розвиткові, забезпечують засвоєння необхідних для роботи з комп'ютером знань і вмінь. У процесі розробки технології структурування програмного забезпечення навчання природничо-математичних дисциплін у педагогічних університетах слід ураховувати, що вона має комплексно охоплювати всі структурні компоненти процесу навчання: цільовий (передбачає усвідомлення викладачем і прийняття студентами мети та завдань дисципліни); мотиваційний (забезпечує стимулювання розвитку в студентів інтересу до дисципліни, потреби у розв'язанні поставлених завдань); змістовий (визначається навчальним планом, державними навчальними програмами та підручниками); операційно-регулятивний (вимагає одночасного здійснення контролю за перебігом та результатами навчального процесу); оціночно-результативний (спрямований на здійснення оцінювання досягнутих студентами результатів, формулювання висновків, з'ясування причин відхилень від запланованих результатів). Метою статті є дослідження необхідності структурування програмного забезпечення природничо-математичних дисциплін як способу досягнення оптимального поєднання різних програмних та інших засобів навчання, що забезпечує формування умінь самостійної пізнавальної діяльності студентів під час вивчення предметів зазначеного циклу. Для розв'язання поставлених завдань використано теоретичні методи (вивчення, аналіз та узагальнення наукової літератури з метою ознайомлення зі станом досліджуваної проблеми); емпіричні методи (спостереження, анкетування, тестування, метод незалежних оцінок для діагностики стану сформованості педагогічної готовності вчителів, педагогічний експеримент - для перевірки ефективності визначеної розробленої технології структурування програмного забезпечення навчання природничоматематичних дисциплін у педагогічних університетах); методи математичної статистики - для обробки результатів експериментальної роботи. Перевірка здійснювалася за наступними критеріями: мотиваційний (рівень сформованості мотивів щодо вивчення природничо-математичних дисциплін); когнітивно-діяльнісний (рівень навчальних досягнень студентів із природничо-математичних дисциплін); професійно-орієнтований (сформованість методичних знань та організаційних умінь у використанні комп'ютерних технологій в процесі викладання природничо-математичних дисциплін у шкільній практиці). Вірогідність визначення результатів педагогічного експерименту було перевірено критерієм Пірсона. Проведений педагогічний експеримент довів доцільність розробленої технології структурування програмного забезпечення навчання природничо-математичних дисциплін, що забезпечує підвищення рівня професійної готовності майбутніх учителів у плані оволодіння й засвоєння матеріалу з природничо-математичного циклу.

Ключові слова: педагогічний університет, програмне забезпечення, структурування, навчання, природничо-математичні дисципліни, майбутні вчителі, експеримент, педагогічна готовість.

Submitted on May, 22, 2017

Reviewed by Doctor of Pedagogy, prof. B. Korotiaiev 